\title{
P03-022 - Calprotec in chronic nonbacterial osteomyelitis
}

\author{
J Brunner \\ From 7th Congress of International Society of Systemic Auto-Inflammatory Diseases (ISSAID) \\ Lausanne, Switerland. 22-26 May 2013
}

\section{Introduction}

The cytoplasmic S100 proteins derived from cells of myeloid origin. Calprotectin (MRP8/14 protein complex) might be a biomarker either for autoinflammation and autoimmunopathy. Since autoinflammatory diseases might be a diagnostic challenge calprotectin may be helpful in the diagnosis of autoinflammatory diseases. Chronic nonbacterial osteomyelitis (CNO) is an autoinflammatory, noninfectious disease. $\mathrm{CNO}$ describes a wide spectrum from a monofocal bone lesion to the chronic recurring multifocal osteomyelitis (CRMO). Laboratory and histopathological findings are nonspecific. In some patients systemic inflammatory signs such as elevated acute phase proteins cannot be found.

\section{Case Report}

To test the ability of Calprotectin (MRP8/14 protein complex) serum concentrations to monitor disease activity in patients with $\mathrm{CNO}$.

\section{Methods}

Serum concentrations of Calprotectin (MRP8/14 protein complex) in a patient with $\mathrm{CNO}$ were determined by a sandwich ELISA.

\section{Results}

Calprotectin (MRP8/14) level were raised heralding active disease when acute phase proteins ( $\mathrm{CrP}$, erythrocyte sedimentation rate). The calprotectin level was $7872,7 \mathrm{ng} / \mathrm{ml}$ (normal range 0-3000 $\mathrm{ng} / \mathrm{ml}$ ).

\section{Discussion}

Calprotectin (MRP8/14) serum concentrations correlate closely with disease activity and may herald a flare before clinical manifestation. Therefore MRP8/14 serum

Pediatrics, Medical University Innsbruck, Innsbruck, Austria concentrations are a biomarker indicating disease activity in $\mathrm{CNO}$ patients.

\section{Competing interests}

None Declared.

Published: 8 November 2013

\section{References}

1. Gerss: Ann Rheum Dis 2012, 71:1991-1997.

2. Hofmann : International J rheumatology 2012, 2012:310206.

\section{doi:10.1186/1546-0096-11-S1-A220}

Cite this article as: Brunner: P03-022 - Calprotec in chronic nonbacterial osteomyelitis. Pediatric Rheumatology 2013 11(Suppl 1):A220.
Submit your next manuscript to BioMed Central and take full advantage of:

- Convenient online submission

- Thorough peer review

- No space constraints or color figure charges

- Immediate publication on acceptance

- Inclusion in PubMed, CAS, Scopus and Google Scholar

- Research which is freely available for redistribution

Submit your manuscript at www.biomedcentral.com/submit
() Bïomed Central

\section{() Biomed Central}

(c) 2013 Brunner; licensee BioMed Central Ltd. This is an Open Access article distributed under the terms of the Creative Commons Attribution License (http://creativecommons.org/licenses/by/2.0), which permits unrestricted use, distribution, and reproduction in any medium, provided the original work is properly cited. 